histological picture was characterized by a massive, almost syncytial growth of reticulum cells with many Reed-Sternberg cells, severe lymphocyte depletion, and absence of eosinophils, plasma cells, or fibrinoid necrosis. This picture was completely different from the entity described as Hodgkin's sarcoma.

Deelman $^{3}$ and I concluded that this disease could be described, both on clinical and on pathological grounds, as a separate entity. I had the opportunity to discuss these cases personally in 1955 with both Dr. F. Parker and Dr. R. J. Lukes, who were at that time rather sceptical about my proposal to mark off this disease from classic Hodgkin's disease as a separate subgroup. However, it should be borne in mind that in 1955 discussions about the immunological nature of Hodgkin's disease were still unheard of. A good account of identical cases had already been given in 1953 by Miss A. M. Hippchen. ${ }^{4}-\mathrm{I}$ am, etc.,

L. OFFERHAUS Departments of Internal Medicine and Biopharmacy, University of Amsterdam,

1 Neiman, R. S., Rosen, P. J., and Lukes, R. J., 751 .

2 Offerhaus, I., Borderline Cases of Hodgkin's Disease. Assen, Van Gorcum and Cie., 1957. Deelman, H. T., Leerboek der Pathologische
Anatomie, vol. III. Haarlem, De Erven, F.

Anatomie, vol., III. Haarlem, De Erven, F.
Bohn N.V., 1962.
4 Hippchen, A. M., M.D. Thesis, Frankfurt, 1953.

SIR,-Immunity may vary widely in individuals and particularly during different stages of a disease. Patients with lymphocytedepleted Hodgkin's disease die rapidly, presumably because the illness is advanced by then and the immunity is almost spent. Untreated cases showing thrombocytopenia were also found in one series at Hammersmith Hospital (unpublished) to have died unusually promptly. The immune changes in this disease may originate some time before the symptoms and signs appear. Until the natural history of the illness is completed, however, the significance of the clinical and histological findings must remain doubtful. The pathological mechanism has to be traced to its source before it can become meaningful.

Both Hodgkin's disease and sarcoidosis sometimes show a familial incidence and blood eosinophilia, and occasionally they are combined.1 2 Moreover, sarcoidosis is more likely to develop into Hodgkin's disease after the infiltration has healed, considering the time factor. Patients with Hodgkin's disease may have the same immune patterns as latestage sarcoidosis, but they do not exhibit the early complications, such as sarcoid hyperthyroidism. During the course of sarcoidosis the immunity may often alter considerably, but usually the aggression is directed only defensively. The humoral response may lead rarely to early and inappropriate endocrine stimulation, and sometimes later to gland failure. ${ }^{3}$ Cell-mediated responses are both active and prolonged in this disorder, ${ }^{4}$ and when they are overactive one result perhaps may be Hodgkin's disease. The four types of Hodgkin's disease ${ }^{5}$ probably arise because the degree of immunity is eventually different in each form. The scars of the immune contest are obvious, but the reason for them is still obscure. Sometimes the sarcoid agent ${ }^{6}$ is possibly responsible for all types of Hodgkin's disease.-I am, etc.,

\section{Chilworth, Surrey}

Gerald A. MACGREGor

1 MacGregor, G. A., Lancet, 1973, 1, 322.

3 Karlish, A. J., And MacGregor, G. A., Lancet, 1970, 2, 330.,

4 Caspary, E. A., and Field, E. J., British Medical fournal, 1971, 2, 143

5 British Medical fournal, 1973, 2, 625. Mitchell, D. N., and Rees, R. J. W., Lancet,
1969, 2, 81.

\section{American Medicine}

SIR,-We enjoyed Dr. I. L. Gregory's visit to this hospital as a locum consultant surgeon in 1970 but did not realize how unobservant he was. He states (7 July, p. 50 ) that in none of the five provincial hospitals where he worked did he find an intermittent positive-pressure breathing machine. May I assure him that at that time we had in the operating theatres of this hospital four such machines and in the intensive care unit four ventilating machines for adults and two for babies and children. For 10 years we have had a 24-hour blood gas analysis service. I cannot, of course, make observations on his other comments abou British or American medicine.-I am, etc.

Peterborough District Hospital,

ROBERT LODER Peterborough.

\section{Serum Immunoglobulins in Ankylosing Spondylitis}

SIR, - We were interested to read that Dr. D. N. Golding (16 June, p. 663) found that one or more of the serum immunoglobulins was abnormal in five of his 10 patients with ankylosing spondylitis. We are currently studying this subject and would like to report our preliminary findings in view of the current interest in the aetiology of ankylosing spondylitis with its high incidence of HL-A $\mathbb{W} 27^{1}$ and the familial and clinical links with other seronegative arthropathies.

Blood samples have been obtained from 25 patients with definite ankylosing spondylitis. Abnormally high results were found for IgG in $10(40 \%)$ and for IgA in $12(48 \%)$, while none had raised IgM or IgD values. Kriege et $a l^{3}$ also found high levels of IgA and slight but insignificantly raised IgG levels in patients with progressive forms of the disease. Even more striking were the markedly raised immunoglobulin levels which we have found in the synovial fluid of patients with peripheral joint involvement. ${ }^{4}$ These observations do not prove anything but suggest that immunological mechanisms may be playing a part in the aetiology of ankylosing spondylitis and are a stimulu for further research in this field.-We are, etc.,

Oueen Elizabeth Hospital

M. J. KeNDALL M. FARR

Birmingham

1 Brewerton, D. A., et al., Lancet, 1973, 1, 904. Wright, V., and Moll, J. M. H.. British foumal of Hospital Medicine, 1973, 9, 331. riegel, W., Burger, R., Kapp, W., and Alexo-
pulos, J., Verhandlungen der deutschen Gesellpulos, J., Verhandlungen der deutschen
schaft für Rheumatologie, 1969, 1, 206.

4 Kendall, M. J., Farr, M., Meynell, M. J., and Hawkins, C. F.,
Hepatitis-associated Antigen in V.D. Clinic Patients

SIR,-The data of Dr. D. J. Jeffries and others (26 May, p. 455) raise some interesting points in relation to the changing views on the mode of transmission of hepatitis B. ${ }^{1-4}$

The increased hepatitis $B$ antigen carrier rate in European homosexuals supports the proposed possibility of venereal transmission of the disease in homosexuals. ${ }^{5}$ Skin and mucous membrane lesions usually present in homosexuals may indeed play some role in transmission. Since such lesions are also present in female prostitutes we should expect that they would also have an increased hepatitis B antigen carrier rate. However, the data presented by Dr. Jeffries and his colleagues argue against venereal spread in the heterosexual sense.

The results of a study to be published soon are in agreement with these findings Thus hepatitis $B$ antigen was found in nine $(3.6 \%)$ out of 247 prostitutes who are regularly referred to us for check-up. A similar frequency $(3.4 \%)$ was found in a sample of 379 pregnant women of similar age and of relatively low socioeconomic level. In view of the above results it would seem appropriate to look for additional reasons for the increased carrier rate among homosexuals.-I am, etc.,

George Papaevangelou

Department of Hygiene and Epidemiology,

University of Athens Medical School,

Athens

1 Krugman, S., and Giles, J. P., fournal of the American Medical Association, $1970,212,1019$.
Cossart, Y. E., and Vahrman, J., British Medical Cossart, Y. E., and Vahrmal, 1970, 1, 403 .

3 Papaevangelou, G.' J., Kourea, T., and Tsoukas, S., Pathologia et Microbiologia, 1971, 37, 361. Hersh, T., Melnick, J. L., Goyal, R. K., and
Hollinger, F. B., New England fournal of Medicine, 1971, 285, 1363. 774.

\section{Hepatitis B Antigen in Ascitic Fluid in Cirrhosis}

SIR,-Hepatitis B antigen (HBAg) is considered to be either the aetiological agent of type B hepatitis or at least closely related to it. ${ }^{1-4}$ This antigen has been demonstrated in the serum of subjects with persistent hepatitis, chronic aggressive hepatitis, and cirrhosis. $^{5-7}$

We have investigated the possible presence of HBAg in ascitic fluid from patients with cirrhosis whose serum was positive for the antigen. Samples of serum and heparinized ascitic fluid were tested for the presence of HBAg by an immunoreoelectrophoretic method, ${ }^{89}$ using kits supplied by Farmitalia Laboratories. The specimens were collected simultaneously from subjects who had not previously undergone paracentesis and care was taken to ensure that the ascitic fluid did not contain blood This study was performed on 12 patients with hepatic cirrhosis in the ascitic phase, eight of whom were HBAg-positive and four negative. The diagnosis of liver cirrhosis was always confirmed by laparoscopy and liver biopsy carried out after collection of the ascitic fluid.

HBAg was found in the ascitic fluid of all eight HBAg-positive subjects at a titre similar to that in the blood. The antigen was not detected in the ascitic fluid of the four HBAg-negative subjects, indicating that the 
positive results were not due to non-specific factors in ascitic fluid.-We are, etc.,

L. Cacciator

V. MOLINAR

V. Guadagnino

P. Tullio Cataldo

Clinic of Infectious Diseases,

II Facoltà di Medicina,

Nuovo Policlinico,

Nappes, Italy

1 Sherlock, S., British Medical Bulletin, 1972, 28,

2 Zuckerman, A. J., British Medical Bulletin, 1972, $28,134$.

Wright, R., British Medical Bulletin, 1972, 28,

120.
Piazza, M.. Di Stasia, G., Maio, G., and Marzano 5 L. A., British Medical foumal, 1973, 2 334. Sherlock, S., Fox, R. A., Niazi, S. P., and
Sheuer, P. J., Lancet, 1970, 1, 1243.

Wancet, i969, 2, 117 . R. W., and Klatskin,

Pesendorfer, F., Krassnitzky, O., and Wewalka, F. Klinische Wochenschrift, $1970,48,58$. $169,593$.

\section{Leptospirosis}

SIR,-Dr. L. H. Turner (3 March, p. 537) states that leptospirosis responds to penicillin-"the fever is terminated within 24 hours." While acknowledging his expert status, I would be interested to learn of any controlled studies on the efficacy of penicillin in this condition.

Having treated scores of proved cases with the dosage of penicillin recommended, sometimes within 12 hours of the onset of symptoms, with no better results than I later achieved with no treatment, I remain sceptical. The patients to whom very early treatment was given, of course, were men whose fellow workers had recently developed leptospirosis.-I am, etc.,

Waitara,

R. D. LOCKHART

New Zealand

\section{Compulsory Admission to Mental Hospital}

SiR,-On the 5 June the Annual Representative Meeting passed a motion in favour of facilitating compulsory admission to a mental hospital under Section 29 of the Mental Health Act 1959. (Supplement, 16 June, p. 95).

The substance of the debate reveals a curious contradiction. While it is made clear that the services of a social worker to make an application are essential only in the absence of a relative, much of the argument in favour of the motion was based on the need for protection of relatives from danger or undue distress. In such circumstances there is a relative available to sign the application so the services of a social worker are not necessary.

In my experience as a psychiatrist it is not the usual practice of local authorities to give statutory powers to social workers with no experience in mental healch. Further, social workers with statutory powers see more situations of severe psychiatric crisis than does the average general practitioner.

Iwant to make he point that these situations typically arouse maximum anxiety in the people involved. The clinical task should centre around the management of anxiety. This will be increased, rather than dimini- shed if debate focuses on the relative expertise and experience of doctors and social workers. Decision-making will become more emotively based and less objective.

I have detailed clinical data which show that only too often a patient can be admitted to a mental hospital for the sole purpose of temporarily relieving anxiety. This is merely palliative and easily becomes repetitive. The more readily it is available the more likely a crisis will be created. In my view it can be quite proper for admission to hospital to be used for the relief of anxiety (either in the patient or others) but in any given situation this should not be the only purpose. To-day a mental hospital exists to provide treatment as well as protection. The use of emergency orders nearly always makes treatment more difficult.-I am, etc.

Wembley, Middlesex

D. C. WALLBRIDGE

SIR, - With reference to Dr. J. E. Duffield's letter (30 June, p. 780), I am surprised that he quotes the relevant section of the Mental Health Act stating the duty of the mental welfare officer at the same time as he criticizes that officer for implementing that section. What could be more appropriate for a mental welfare officer seeking to satisfy himself that an application ought to be made than for him to question the doctors involved, whose qualifications make their comments on the patient's illness of particular importance?

Perhaps Dr. Duffield is really questioning that part of the Act which involves a mental welfare officer in these applications and would prefer the decision about compulsory admission and its implementation to be left to the doctors concerned? It is possible, however, that society would not be happy at leaving a decision depriving someone of his liberty to any one profession. Therefore, if the social worker's participation were no longer legally required, a substitute might well need to be found. -I am, etc.,

J. R. FeLls Oxford Assistant Director (Fieldwork Services),
City of Oxford Social Services Department

\section{Fatal Pancytopenia after Administration of} Fortagesic

SIR,-Agranulocytosis of varying prognosis has been reported as occurring with a number of drugs. I am not aware of any reported case of fatal agranulocytosis associated with paracetamol ( $N$-acetyl-p-aminophenol). One case of agranulocytosis following paracetamol administration was reported by Lloyd; ${ }^{1}$ his patient, a woman of 78 , recovered after discontinuation of paracetamol. I am reporting a case of fatal pancytopenia after administration of paracetamol in combination with pentazocine (Fortagesic). Since paracetamol is known to cause thrombocytopenia ${ }^{2}$ it might be reasonable to assume that in this case paracetamol was the offending agent rathe than pentazocine, but there can be no certainty on this point.

A 77-year-old woman was admitted on 7 March 1973 with a three-day history of bleeding per vaginum and epistaxis. She had always enjoyed good health and had had no illness of any signifi- cance in the past. On 14 February she went to see her own doctor for what was stated to be "sciatica" She was prescribed Fortagesic tablets (containing pentazocine base $15 \mathrm{mg}$ and paracetamol $550 \mathrm{mg}$ ) two tablets four times a day. She was given 50 tablets and consumed them over a week, when another 50 tablets were prescribed, of which 40 were consumed by 4 March, when she started having epistaxis. Her haemoglobin level, requested by her general practitioner, was reported to be $35 \%$. The drug was stopped and the patient admitted to hospital on 7 March. On admission she looked pale and ill but her temperature was normal. There wras extensive purpura mostly affecting the legs and face (see fig.). The liver and spleen were not palp-

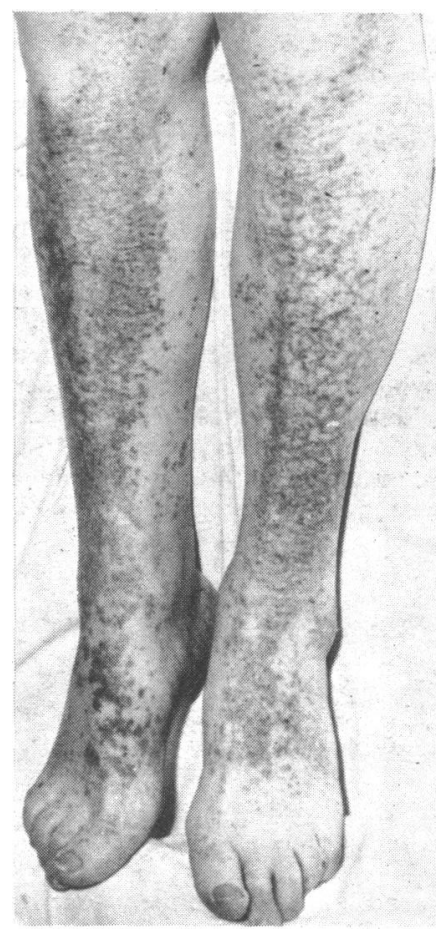

able. Chest $x$-ray showed clear lung fields. Blood count showed haemoglobin $6.7 \mathrm{~g} / 100 \mathrm{ml}(45 \%)$ platelets 9,000/mm , E.S.R. $75 \mathrm{~mm}$ in $1 \mathrm{hr}$, and white cell count 1,700/mm (neutrophils 1,000, lymphocytes 660 , monocytes 20 , and cosinophils $20 / \mathrm{mm}^{2}$. Bone marrow examination confirmed the presence of hypoplasia; there were marked reductions in the erythroid and myeloid series and no megakaryocytes were seen. The patient was treated with blood transfusions followed by platelet transfusions. Other supportive therapy-for example, folic acid, iron, hydroxocobalamin, oxymetholone, etc. -was also instituted. After an initial improvement her condition steadily deteriorated and she died on 6 May. Her last blood count showed haemoglobin $7.0 \mathrm{~g} / 100 \mathrm{ml}(48 \%)$, platelets $8,000 /$

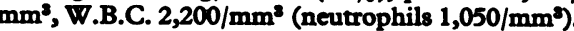
Postmortem examination did not reveal anything significant except marrow aplasia. The patient's relatives and her G.P confirmed that she had taken no drug other than Fortagesic before admission to hospital.

In conclusion, it must be stated that considering the quantity of paracetamol consumed every week the fatal side effects must be very rare indeed. Fortagesic is a new preparation, and whether pentazocine in combination with paracetamol alters the effect of the latter in any way remains to be seen.-I am, etc.

S. B. DATT

Geriatric Unit, St. Luke's Hospital,

1 Lloyd, T. $W_{\text {; }}$ Lancet, 1961, 1,114 2 Thomas, J. H., and Poweli, D. B. B. Blood Dis- 